\title{
"Gente humilde": um tema, duas canções
}

\section{RODRIGO APARECIDO VICENTE*}

\begin{abstract}
RESUMO: Neste estudo, são analisadas duas versões de "Gente humilde" (Garoto), obra originalmente composta para violão que recebeu, entre 1950 e 1970, duas interpretações na forma de canção. A primeira, de autoria desconhecida, é uma narrativa em terceira pessoa que busca representar um espaço sócio-geográfico habitado pelos grupos menos favorecidos economicamente, traduzindo um imaginário para o qual esse espaço se constitui enquanto reserva de "pureza" e "felicidade". Já na segunda versão, assinada por Vinicius de Moraes e Chico Buarque, ouve-se um momento de autorreflexão de um individuo sensibilizado com a precariedade das condições sociais de existência dos mais "humildes", oscilando, contudo, entre uma postura mais consequente do ponto de vista politico e outra marcada pela tentativa de retorno a um modo de vida comunitário. Tanto na primeira versão, narrada por uma espécie de "voz social", quanto na segunda, que aponta para a crise de uma autoimagem orientada pelo ideal de "povo" e "nação" enquanto "totalidade", constata-se que a condição de pobreza acaba por ser naturalizada. Neste artigo, procurar-se-á demonstrar como essa naturalização pode ser identificada a partir de uma análise formal das obras que enfatize as ambivalências e contradições inscritas em suas estruturas.
\end{abstract}

PALAVRAS-CHAVE: Canção Popular Brasileira; décadas de 1950 e 1960; "Gente Humilde"; condição de pobreza.

\section{"Gente humilde": a theme, two songs}

ABSTRACT: In this paper, two versions of the lyrics written between 1950 and 1970 for "Gente Humilde", originally composed by Garoto for guitar, are analyzed. The first one, written by an unknown songwriter, is a third-person narrative that seeks to represent a socio-geographical environment inhabited by economically disadvantaged groups, reflecting an imaginary for which this environment is constituted as reserve of "purity" and "happiness". In the second version, than signed by Vinicius de Moraes and Chico Buarque, it is possible to hear a moment of self-reflection of a sensitized individual to the precarious social conditions of existence of the "humble", oscillating, however, between a more consequent political point of view and by the attempt to return to a communal living. The condition of poverty turns out to be naturalized both in the first version, narrated by a kind of "social voice", and the individuality expressed in the lyrics of Vinicius and Chico, which points to the crisis of self-image guided by the ideal of "people" and "nation" as "totality". In this paper, we intend to demonstrate how this naturalization can be identified from a formal analysis of the works that emphasize the ambivalences and contradictions inscribed in their structures.

KEYWORDS: Brazilian Popular Music; 1950s and 1960s; "Gente Humilde"; Poverty Condition.

\footnotetext{
* Rodrigo Aparecido Vicente é doutor em Música pela UNICAMP. Tem experiência na área de Estudos de Música Popular e História da Música Popular Brasileira. Em 2014, ingressou no curso de graduação em Filosofia da UNICAMP. E-mail: rodrigovicente86@gmail.com
} 


\section{O anonimato de uma voz social}

Cada pessoa só é capaz de dizer "eu" se e porque pode, ao mesmo tempo, dizer "nós". Norbert Elias - A sociedade dos indivíduos

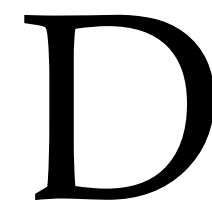
e volta à Rádio Nacional no início dos anos 1950, Garoto - Aníbal Augusto Sardinha (1915-1955) -, que havia deixado esta emissora em meados de 1948, protagoniza a estreia de diversos programas como o Música em Surdina, Dedos Mágicos e Solistas da Rádio Nacional. O multi-instrumentista gozava à época de amplo prestígio no meio artístico, sendo frequentemente destacado pelos seus pares em função de sua versatilidade, virtuosismo e pela qualidade de suas composições. A este domínio, aliás, Garoto vinha se dedicando com mais intensidade desde a década anterior, compondo canções - quase sempre com um parceiro letrista - e músicas instrumentais, sobretudo para violão solo (ANTONIO \& PEREIRA, 1982).

Foi nesse contexto que surgiu "Gente humilde". De acordo com um de seus biógrafos, o pesquisador Jorge Mello, Garoto compôs essa obra por volta de 1945, então inspirado por uma de suas visitas ao subúrbio da cidade do Rio de Janeiro, ocasião em que havia se sensibilizado com a paisagem humana, com as condições materiais e sociais de existência das pessoas que ali viviam. Além disso, sabe-se que "Gente humilde" integrava uma pequena suíte para violão ao lado de outras duas composições: “Vivo sonhando" e “Meditação” (MELLO, 2012, p. 119-20).

Mas foi apenas em 1951 que "Gente humilde" recebeu a sua primeira letra. Em depoimento, o cantor e arranjador Badeco (Emmanuel Barbosa Furtado), exintegrante do conjunto vocal Os Cariocas e amigo íntimo de Garoto por essa época, afirmou que o interesse em escrever uma letra para a composição partiu de um antigo parceiro, chamado Moacir Portes. Este, por sua vez, pediu a Garoto as partituras de "Gente humilde" e "Meditação", a fim de mostrá-las a alguns amigos numa viagem que faria ao estado de Minas Gerais. Assim que retornou com as respectivas le- 
tras para as composições, Moacir Portes logo as apresentou a Garoto, tendo este se entusiasmado com o resultado e indagado acerca da autoria das mesmas. A resposta, todavia, foi a de que o suposto autor, um amigo muito discreto, que não queria "aparecer" - um verdadeiro "bicho do mato", segundo suas próprias palavras - era o responsável pelas letras. Este autor havia apenas recomendado que, caso Garoto aprovasse o trabalho, bastava apenas mencioná-lo como “autor desconhecido" ${ }^{1}$

A primeira apresentação de "Gente humilde" se deu em novembro de 1951, no programa Ondas Musicais, da Rádio Nacional. ${ }^{2}$ Badeco escreveu, na ocasião, um arranjo apenas para vozes, de caráter contrapontístico e grandiloquente, que contava com a participação dos conjuntos vocais Os Cariocas, Trio Madrigal e Trigêmeos Vocalistas; das cantoras Zezé Gonzaga e Belinha Silva; e do coro da Rádio Nacional. Juntos, esses artistas formavam o coral Cantores do Céu. A letra dessa versão, de autoria desconhecida, era a seguinte:

Em um subúrbio afastado da cidade

Vive o João e a mulher com quem casou

Em um casebre onde a felicidade

Bateu à porta foi entrando e lá ficou.

E à noitinha alguém que passa pela estrada

Ouve ao longe o gemer de um violão

Que acompanha

A voz da Rita numa canção dolente

É a voz da gente humilde que é feliz.

A escassez de informações acerca do autor e do ambiente a que este pertencia impõe uma série de dificuldades para uma análise formal que revele em igual medida os dados sociais e históricos sedimentados na estrutura da obra. No entanto, há algumas indicações na própria letra que, uma vez cotejadas com o contexto de sua

\footnotetext{
${ }^{1}$ Essas informações se encontram disponíveis na série Cancioneiro Garoto, organizada por Jorge Mello em parceria com o site Sovaco de Cobra. Ver: MELLO, 20 set. 2013.

${ }^{2} \mathrm{O}$ áudio da primeira versão está disponível para audição em: MELLO, 20 set. 2013. Por ter sido gravada a partir dos acetatos de 16 polegadas da Rádio Nacional, sua qualidade sonora é bastante precária, impedindo-nos de empreender uma análise mais precisa acerca dos elementos e procedimentos constituintes da performance.
} 
produção e conduzidas à luz da estrutura musical e das motivações iniciais de Garoto quando da sua criação, possibilitam-nos empreender alguns comentários.

Observa-se de saída a intenção do autor em respeitar e aproveitar a ideia e a inspiração primeira de Garoto, a saber, a de tentar traduzir esteticamente o que havia sentido e percebido quando esteve em contato com o espaço do subúrbio. Esta coerência é igualmente mantida na letra escrita por Vinícius de Moraes e Chico Buarque, em 1970, conforme discutiremos no próximo item. Ocorre, porém, que no verso inicial do autor mineiro nota-se logo a oposição subúrbio x cidade, ou seja, a ligação entre ambos parece ser mais remota do que propriamente a de um bairro localizado nas adjacências do centro urbano. Essa dicotomia é reforçada no quinto verso (início da segunda estrofe), quando o sujeito lírico se refere a "alguém que passa pela estrada". É provável que "estrada", aqui, não corresponda a uma simples rua ou avenida, mas a uma estrada de terra, remetendo o ouvinte, dessa forma, a um meio situado entre o campo e a cidade, talvez já em vias de urbanização.

A partir desses comentários iniciais, tem-se uma ideia mais clara do ambiente e das fontes que orientaram o "autor desconhecido" em seu processo criativo. Isso porque as imagens por ele erigidas parecem representar poeticamente um espaço (real ou não) $)^{3}$ situado na fronteira que separa os universos rural e urbano. De maneira mais remota, o caráter narrativo de sua letra aponta ainda para uma característica própria das manifestações artísticas do "homem rústico", para falar com Antonio Candido: a coletividade na criação, no trabalho, nas atividades da comunidade de uma forma geral, em contraposição à individualidade, tão cara ao homem civilizado,

\footnotetext{
${ }^{3}$ Ao relativizar a possibilidade de o autor estar representando uma realidade "concreta" ou "fictícia", estamos interessados menos em identificar as correspondências entre o poema e um meio social real, que em apreender a coerência "interna" da elaboração artística, ou seja, importa-nos, sobretudo, investigar como as escolhas estéticas e a organização interna da obra podem constituir e representar uma "realidade" própria. Para Antonio Candido, esta é uma das características centrais da obra de ficção, qual seja, a de sempre fornecer uma "interpretação" da realidade, mas nunca a realidade "de fato", uma vez que o trabalho do artista é o de "modificação" desta, e não o da sua "reprodução" - se assim o fosse, não teríamos obras de arte, mas simples descrições da realidade. Ainda segundo o autor, "dada a circunstância de ser o criador da realidade que apresenta, o romancista, como o artista em geral, domina-a, delimita-a, mostra-a de modo coerente, e nos comunica esta realidade como um tipo de conhecimento que, em consequência, é muito mais coeso e completo (portanto mais satisfatório) do que o conhecimento fragmentário ou a falta de conhecimento real que nos atormenta nas relações com as pessoas." (CANDIDO, 1992, p. 64).
} 
ao artista "moderno". 4 Todavia, a opção pelo anonimato denuncia, ao mesmo tempo, uma postura igualmente cara àqueles que não desejam confundir suas atividades profissionais com o ramo do entretenimento, denotando em última análise uma estratégia de distinção social. ${ }^{5}$ Acredita-se que esta hipótese é a mais plausível para este caso, conforme discutiremos ao longo deste estudo.

Logo após a indicação do lugar que está procurando representar, o sujeito lírico menciona as personagens centrais do poema e especifica um pouco mais o cenário em que se situam. "João e a mulher com quem casou” constituem, possivelmente, uma união recente, e encerram o núcleo familiar. A mulher é identificada apenas na segunda estrofe (Rita), cuja voz é acompanhada pelo violão "numa canção dolente". No geral, percebe-se que se trata de um ambiente humilde de fato, composto de um "casebre", e não de uma casa comum. Apesar da precariedade estrutural daquele meio, depreendida neste fragmento, João e Rita vivem, na percepção do sujeito lírico, em harmonia, num lugar "onde a felicidade bateu à porta, foi entrando e lá ficou". Note-se que a "felicidade", entendida enquanto estado de alegria permanente, é mencionada aqui como uma "conquista", ou seja, supõe-se a partir dessa referência que houve um momento inicial em que o casal sofria os dissabores causados pelas condições materiais e sociais de existência da "gente humilde". Mas é igualmente notável o fato de que a nova condição - a conquista da felicidade - parece ter se instaurado sem uma mudança "estrutural" efetiva, afinal, João e Rita continuam no "casebre", no "subúrbio afastado da cidade". Nesse sentido, é como se o autor estivesse naturalizando a condição, historicamente determinada, de pobreza, visto que esta não foi superada pelo casal - retornaremos a essa discussão mais adiante.

Com os elementos reunidos até aqui, podemos partir para uma análise mais extensiva da obra. A primeira estrofe já indica a dinâmica e o caráter geral do

\footnotetext{
${ }^{4}$ Em alguns estudos de Antonio Candido, termos como "homem primitivo", "rústico" e "civilizado" são empregados enquanto parâmetros analíticos que diferenciam manifestações artísticas de meios sociais específicos, afastando-se, portanto, da intenção valorativa ou depreciativa que essas classificações podem eventualmente engendrar. Uma das particularidades da arte e literatura de tradição oral (primitiva e rústica), por exemplo, é a autonomia reduzida do artista ou autor, cuja obra, por outro lado, exerce papel mais significativo na organização da sociedade. Ver: CANDIDO, Antonio. "Estímulos da criação literária". In: CANDIDO, 2010, p. 54.

${ }^{5}$ Sobre a noção de distinção, ver: BOURDIEU, Pierre. “O senso da distinção". In: BOURDIEU, 2008, p. 241-7.
} 
poema, a saber, de que se trata da tematização de um espaço social (real ou não) habitado pelos grupos de baixa renda, cujas condições de vida são precárias - ainda que não possamos saber o nível dessa precariedade. Acontece, porém, que essas imagens não são erigidas por alguém que se encontra nas situações descritas, ou seja, por alguém que fala "de dentro". Ao contrário, o sujeito lírico é o observador, que fala "de fora", aquele que passa pelo subúrbio, mas não vive ali. No primeiro caso, poderíamos supor, as dificuldades e limitações inerentes às condições de vida não seriam articuladas num discurso em que a felicidade parece prevalecer, pois, uma vez situado naquele contexto, o sujeito lírico deixaria transparecer ao menos um tom nostálgico, aludindo a um estado de alegria menos imediato, talvez um pouco distante no tempo e no espaço. Deixando de lado o plano hipotético, deve-se ressaltar que esse caráter até pode ser identificado no poema, mas em um nível secundário. Referimonos aqui a dois versos específicos presentes na segunda estrofe, que falam do "gemer de um violão, que acompanha a voz da Rita numa canção dolente". Não se trata de uma canção "alegre", "eufórica”, como se pode notar, embora o autor conclua dizendo que a voz que a interpreta "é a voz da gente humilde que é feliz". São suscitados, ainda que em sentido figurado e de maneira periférica no contexto da obra, gestos e sentimentos aflitivos, internos às personagens, como se o "gemer" do violão e a "canção dolente" estivessem representando, metaforicamente, a manifestação de impulsos e necessidades situados num plano mais subjetivo e sensível da própria "gente humilde". Isso nos remete invariavelmente à própria subjetividade e sensibilidade do autor, à sua "visão de mundo", a qual inclui a "dolência" onde supostamente predomina a "alegria".

Não obstante, prevalece na obra uma visão otimista e, portanto, distante do contexto narrado, haja vista o modo como cada estrofe é concluída, por exemplo: "a felicidade" que "bateu à porta, foi entrando e lá ficou", de um lado; "a voz da gente humilde que é feliz", de outro. Em ambos os casos, o sentimento de felicidade ganha força justamente porque os versos estão localizados nos instantes conclusivos. Daí sustentarmos a hipótese de que prevalece a visão "externa", não integrada ao meio social do subúrbio e que, ao voltar-se para este, o interpreta em chave idílica. Diga-se de passagem, esta visão distanciada em relação ao "populário" constitui um 
imperativo no cancioneiro popular nacional, encerrando uma visão de determinados setores da classe média que tenciona superar as contradições sociais no plano estético.

No entanto, nesse processo de transfiguração estética, as marcas do meio social e cultural que inspiraram o autor desconhecido, assim como as marcas das manifestações artístico-literárias típicas de um mundo situado entre o campo e a cidade, que também possivelmente o inspiraram, estão presentes na forma e no conteúdo da canção. Em outras palavras, há indícios de que a "poiese" do autor anônimo não corresponda tão somente a uma transfiguração estética em que a realidade - as forças sociais reais, o espaço sócio-geográfico etc. - é dissimulada a tal ponto que não seja possível identificá-la. Na verdade, os traços propriamente sociais que o conteúdo poético desta primeira versão representa são também constituintes da sua estrutura, ou seja, inscrevem-se na sua forma, encontram-se diluídos na mesma solução daquilo que identificamos até aqui como sendo o especificamente "estético". De certo modo, o caráter narrativo e um tanto quanto linear da letra, a descrição do espaço social representado, enfim, remetem-nos às canções de temática sertaneja ou caipira, tendência em voga no campo da música popular na década de 1950, ao lado do sambacanção, do baião e da música folclórica. A autonomia do autor inserido nessa tradição parece ser menos evidente, embora sua obra adquira maior relevância numa organização social de tipo comunitário, por exemplo (CANDIDO, 2010, p. 54). Daí talvez a relevância da narrativa em terceira pessoa nesta versão, como que representando uma coletividade, um "nós" mais do que um "eu”. Antes de avançar nessa discussão, julgamos necessário nos remeter ao conteúdo propriamente musical de "Gente humilde", articulando-o com a letra que vimos comentando anteriormente.

De acordo com a versão original composta por Garoto, essa canção está localizada na tonalidade de Sol Maior. ${ }^{6}$ Metricamente, encontra-se dividida em compassos de quatro tempos, afastando-se, nesse sentido, do samba e do choro, assim como do samba-canção - neste caso, devido à ausência de acentos nos tempos 1 e 3, considerando-se a sua escrita em compasso quaternário -, gêneros recorrentes na

\footnotetext{
${ }^{6}$ A fim de facilitar os cotejamentos, as versões analisadas neste estudo foram transpostas para a tonalidade de Sol Maior.
} 
produção desse violonista. Outro elemento que reforça essa distinção é a sua figuração rítmico-melódica, formada basicamente por colcheias regulares, com alguns repousos em notas de longa duração nas conclusões de frases. Seria arriscado, portanto, associar "Gente humilde" a algum gênero específico, ao menos dentre os mais conhecidos no campo da música popular na época de sua criação e divulgação. Seu andamento lento, sua pulsação regular, a ausência de síncopas e sua figuração rítmico-melódica baseada em colcheias, de fácil memorização, aproximam-na de algumas serestas, toadas, canções folclóricas (cf. a partitura completa no anexo).

É importante lembrar que estamos considerando, até aqui, sua versão instrumental. Além disso, não devemos esquecer os aspectos harmônicos, os quais assumem importância decisiva na interpretação e na construção de sentidos da composição. E é no confronto entre melodia, harmonia e letra que se observa logo nos versos iniciais certos contrastes e correspondências entre a estrutura musical e o conteúdo poético.

Quando se canta "Em um subúrbio afastado da cidade", as notas de apoio da melodia sublinham notas estruturais dos acordes: a quinta justa do acorde de G6; a quinta diminuta de $\mathrm{Bb}^{\circ}$; e a sétima menor de $\mathrm{Am} 7$, já na conclusão da primeira frase. Este fragmento pode ser considerado como o antecedente. Como se pode observar, as notas que compõem a melodia pertencem às estruturas dos acordes, desenhando uma linha ascendente e pouco dissonante, reforçando assim o caráter "singelo" - não eufórico, portanto - tencionado pelo sujeito lírico - a resolução momentânea num acorde menor parece corroborar esse caráter.7 Já no consequente - a "resposta" à frase anterior, construída descendentemente - um sentido análogo pode ser identificado. Em "vive o João e a mulher com quem casou" as notas da melodia apresentam, respectivamente, uma consonância imperfeita e uma dissonância em relação aos acordes que secundam o referido trecho: a décima terceira maior de D7 (a dominante da tonalidade); e a sétima maior de G7M (acorde de tônica), já na resolução. As consonâncias imperfeitas, vale lembrar, estão situadas a meio caminho das perfeitas e daquilo que

\footnotetext{
7 A relação consonância/dissonância, adotada neste estudo para fins analíticos, não deve ser entendida enquanto uma generalização. Acreditamos apenas que cada obra apresenta uma gama de sonoridades que oscila entre um grau maior ou menor de tensão, ainda que esta classificação não seja precisa e tampouco válida para outras obras.
} 
conhecemos como dissonância, ou seja, são passíveis de adquirir, dependendo do contexto, algum nível de tensão. E é isso o que se constata na relação melodia/harmonia nesse momento: o acorde dominante (D7) é formado, como se sabe, pelo trítono (quarta aumentada ou quinta diminuta), uma tensão acentuada; e o fato de a melodia repousar na sétima maior (dissonância) de G7M - a sensível da tonalidade - já na conclusão, e não em sua nota fundamental (Sol), confere um grau de tensão ao fragmento (ver Fig. 1).

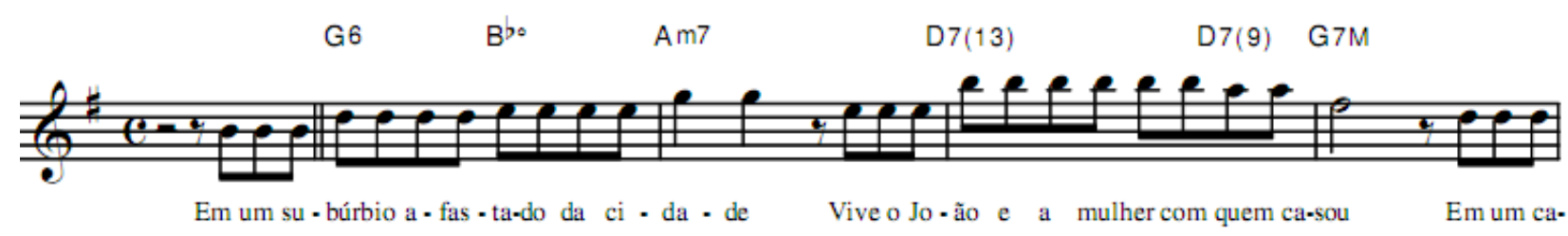

Fig. 1: Fragmento inicial de "Gente Humilde" (primeira versão com letra - 1951).

Os versos seguintes corroboram o sentido descrito anteriormente, sobretudo no instante conclusivo da primeira estrofe. O eu lírico se refere ao "casebre onde a felicidade bateu à porta, foi entrando e lá ficou". Ao final deste verso, a melodia também repousa na sétima maior do acorde de G7M, sendo este igualmente precedido por um acorde dissonante - Ab7(\#11), substituto da dominante (D7) -, enfraquecendo assim, ainda que discretamente, a representação de um ambiente isento de conflito, então explícito na letra (ver Fig. 2).

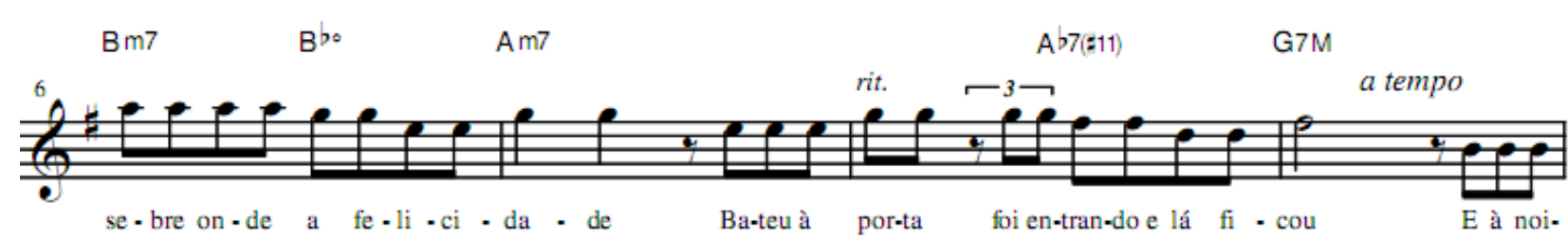

Fig. 2: Conclusão da primeira estrofe de "Gente Humilde" (primeira versão com letra - 1951).

Em contraste, no final da segunda estrofe, o fragmento que corresponderia à estrutura melódico-harmônica comentada anteriormente apresenta um sentido distinto. Trata-se do instante em que se canta o verso "É a voz da gente humilde que é feliz". Até a primeira sílaba da palavra "humilde", a nota da melodia permanece na quinta diminuta do acorde de Am7(b5), estrutura que pode ser interpretada como 
uma substituição da subdominante menor (Cm6). Porém, após a passagem pela dominante da tonalidade (D7), a melodia conclui no acorde de G6 e, para reforçar o sentido de resolução, ocorre o repouso na nota fundamental (Sol). Este procedimento acaba por reiterar o conteúdo da letra, dirimindo as tensões antes prevalecentes, ainda mais quando se ouve a palavra "feliz" coincidindo exatamente com a fundamental do último acorde (G6) - que, por sinal, é formado por uma tríade maior (ver Fig. 3).

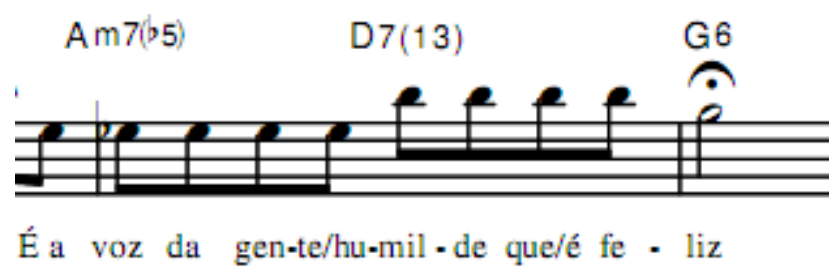

Fig. 3: Último verso da primeira versão de "Gente Humilde" (primeira versão com letra - 1951).

Diante dessas considerações, é preciso destacar o aspecto que vem se revelando imperativo neste estudo: a oscilação entre sentidos opostos, conflitantes, mas que não se anulam, que coexistem. Em outras palavras, devemos considerar a ambivalência de "Gente humilde" um traço constitutivo da obra. Ambivalência que, como se viu, torna-se mais evidente na medida em que a interpretação inter-relaciona o conteúdo poético, que remete a um estado de felicidade, e a estrutura musical, que parece tensionar esse estado. E é neste instante que devemos retomar a argumentação iniciada antes da análise formal, a fim de esclarecer o modo como se constitui o caráter dialético da obra e redimensionar as hipóteses levantadas até aqui.

No tocante à dimensão social tornada aparente pelo conteúdo poético, tanto em função do caráter descritivo daquele cenário - procedimento típico na música de temática caipira ou sertaneja, conforme já destacamos, em que a remissão à subjetividade do sujeito lírico é dissimulada em favor da objetividade do contexto narrado -, quanto pela presença de versos como “Em um subúrbio afastado da cidade" e “E à noitinha alguém que passa pela estrada" (remissão a um espaço situado na fronteira do meio rural e urbano), vimos que a tonalidade maior, a figuração rítmica regular e a recorrência de acordes e intervalos melódicos consonantes sublinhando esses ver- 
sos vão ao encontro do caráter algo "ingênuo", "simples" e "feliz" tencionado pelo letrista anônimo. Todavia, o modo como Garoto concebeu sua obra comporta, na mesma proporção, estruturas melódico-harmônicas dissonantes, resoluções em tensões e progressões harmônicas que se afastam da ideia de "simplicidade" e conferem à composição sentidos mais ambíguos. Em versos como “Ouve ao longe o gemer de um violão que acompanha// A voz da Rita numa canção dolente", por exemplo, aquele estado de "felicidade" hegemônico se enfraquece, deixando transparecer a face "melancólica" da letra, haja vista o sentido metafórico que adquirem as palavras "gemer" e "dolente", denotando certa "tristeza" ou "sofrimento".

O primeiro desses versos é secundado por uma progressão formada pelos acordes de D7(13) - D7(b9) / Bm7(b5) - E7(b9), ou seja, estruturas na maior parte do tipo dominante acrescidas de extensões (ver Fig. 4).

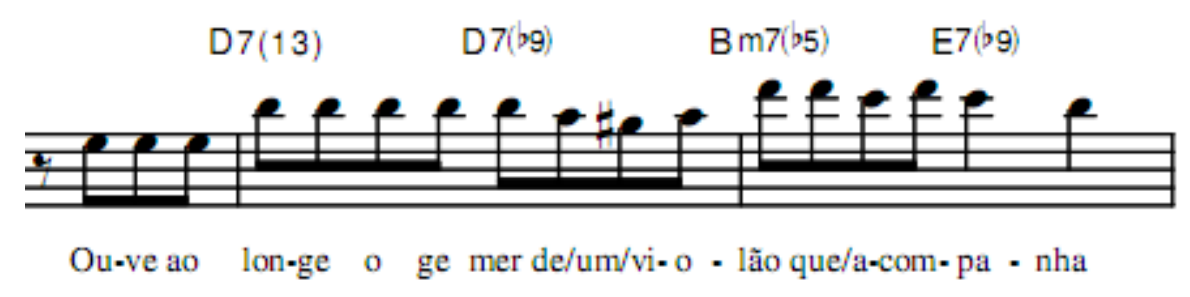

Fig. 4: Instantes finais da primeira versão (com letra) de "Gente Humilde".

Quanto ao verso seguinte, destaca-se a presença de uma fermata sobre a nota Fá sustenido, que coincide com a última sílaba da palavra "dolente", enquanto a progressão harmônica apresenta o acorde de $\mathrm{Bb}^{\mathrm{o}}(\mathrm{b} 13)$. A tensão resultante dessa combinação parece reforçar o caráter aflitivo explícito na letra (ver Fig. 5).

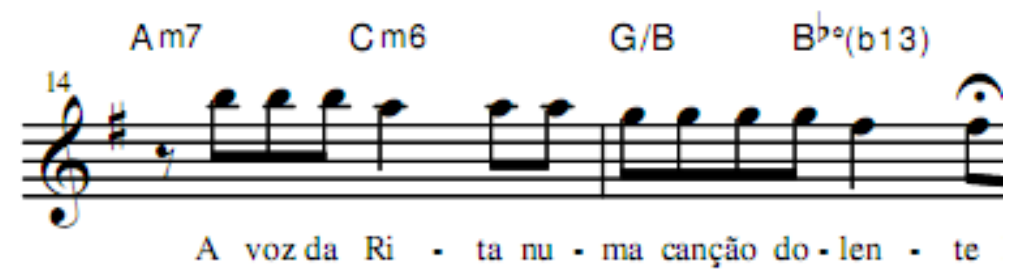

Fig. 5: Penúltimo verso de "Gente Humilde" (primeira versão com letra - 1951).

Esses versos assinalam um momento em que a descrição de um cenário real, então predominante na obra, tende a se desvanecer, permitindo ao sujeito lírico 
representar traços mais subjetivos e sensíveis das personagens, remetendo-nos então, conforme sublinhamos, à sua própria subjetividade e sensibilidade, a qual parece apreender aquele meio enquanto reserva de "alegria" e "inocência" mesmo quando é manifestado um sentimento de "tristeza".

O fato de esta letra traduzir uma representação que certos grupos da classe média brasileira sustentam ante o nosso "populário", a qual parece naturalizar a condição de pobreza ao transfigurá-la esteticamente, não significa que este gesto corresponda a uma ação plenamente consciente, deliberada ou voluntária. De certa forma, enquanto ideologia, essa representação encerra um momento de verdade e um momento de falsidade ${ }^{8}$ : por um lado, é verdadeira na medida em que o eu lírico se identifica e se mostra sensibilizado ante os menos favorecidos e suas condições materiais e sociais de existência; por outro, é falsa por este acreditar na superação desse estado conflituoso sem que antes tenha havido uma transformação social concreta, acabando assim, contraditoriamente, por naturalizar esse estado via elaboração estética. Em suma, para além de uma manifestação artística individual, cuja "identidade" nos foi ocultada, ouve-se na primeira versão de "Gente humilde" uma voz que, no fundo, é social, à medida que traduz um imaginário que orienta certas frações da classe média brasileira, as quais tomam o elemento popular enquanto fonte de "pureza", "inocência" e "felicidade".

\section{Um "eu-nós" em crise}

Contradições e ambivalências análogas podem ser encontradas na versão composta por Vinicius de Moraes e Chico Buarque, que integra o disco Chico Buarque de Hollanda $n^{\circ} 4$. Todavia, o modo como esta nova interpretação se estrutura é sensivelmente distinto da primeira, adquirindo novos sentidos à luz de seu contexto de produção.

8 Sobre a noção de "ideologia", na perspectiva da crítica dialética de orientação marxista, ver: ADORNO, 1986. 
Segundo Vinicius de Moraes, ${ }^{9}$ numa fala registrada em 1975 quando de um show realizado no Teatro Castro Alves, em Salvador (BA), "Gente humilde" havia sido lhe apresentada por Baden Powell, ainda em sua versão instrumental, no início da década de 1960. Este violonista, por sua vez, afirmou que fora Zé Menezes José Menezes França (1921-2014) -, multi-instrumentista e amigo íntimo de Garoto, quem havia lhe apresentado essa composição. ${ }^{10} \mathrm{O}$ importante a destacar é que nesse processo de transmissão oral a melodia e a harmonia dos últimos quatro compassos da canção foram sensivelmente modificadas, conforme discutiremos a seguir, embora não se saiba quem é o responsável por tais alterações - se Zé Menezes, Baden Powell ou o próprio Garoto. ${ }^{11}$

Voltando ao testemunho de Vinicius de Moraes, este logo esclarece que procurou respeitar "a ideia de Garoto", tendo sido "muito condicionado pelo título que ela tinha há muito tempo". O poeta conta que se inspirou na paisagem do subúrbio do Rio de Janeiro, então vista da janela dos trens da Central do Brasil no caminho entre Rio e São Paulo. Por essa época (de 1965 a 1967), Vinicius viajava constantemente à capital paulista para participar do programa de Elis Regina, “O Fino da Bossa", apresentado pela TV Record. As viagens se davam de trem em virtude do "medo total de avião" que o acometia naquele período, medo este superado anos depois graças à sua "Mãe Menininha do Gantois". ${ }^{12} \mathrm{E}$, sempre que retornava de São Paulo, passando pelo subúrbio carioca, o "tema de Garoto voltava", e ele "sentia então ligado com aquele mundo empoeirado, aquela gente sem ver... Aqueles velhinhos de

\footnotetext{
${ }^{9}$ Ver: MELLO, 20 set. 2007.

${ }^{10}$ Em entrevista concedida ao autor deste trabalho em julho de 2011, Zé Menezes lembra que, em meados dos anos 1950, o então jovem Baden Powell costumava frequentar sua casa a fim de tomar algumas aulas de violão.

${ }^{11}$ Aliás, Zé Menezes executa "Gente humilde" com essas alterações em várias performances, algumas das quais podem ser ouvidas através dos seguintes endereços eletrônicos: http://www.youtube.com/watch?v=VMI43XoxlUc;

http://www.youtube.com/watch?v=zN4K2k7iZiU. Neste vídeo, Zé Menezes frisa que aprendeu as músicas de Garoto com o próprio violonista, dispensando as partituras.

12 Este é o nome como ficou conhecida Maria Escolástica da Conceição Nazaré (1894-1986), soteropolitana e principal Iyálorixá do histórico "Terreiro do Gantois", de Salvador-BA. Entre os anos 1960 e 1970, Mãe Menininha do Gantois gerou polêmica ao permitir a participação de brancos e católicos nas atividades do terreiro. Esse fato coincide com a fase em que Vinicius se aproxima da cultura afro-brasileira, ao lado de Baden Powell. A principal expressão artística resultante desse trânsito, como se sabe, é o disco Os Afro-sambas (1966).
} 
pijama naquelas varandas. (...) sentia que Garoto tinha realmente querido falar daquela gente, da gente do subúrbio".

A segunda letra para a canção seria composta pouco tempo depois, quando Vinicius visitou Chico Buarque no período de seu autoexílio, na Itália. De acordo com o então jovem compositor, sua participação na letra se deu após muita insistência do poeta, e se resume aos versos "Pela varanda flores tristes e baldias, como a alegria que não tem onde encostar". Em uma entrevista concedida anos mais tarde, Chico admitiu que, embora esses versos tenham recebido aprovação imediata de Vinicius, ele próprio não sabia o que significavam. O incentivo do amigo e poeta consagrado foi importante para o jovem compositor que, àquela altura, não vivia uma boa fase, haja vista o seu afastamento do país motivado pela opressão, repressão e censura instauradas durante o governo militar, então em pleno recrudescimento (WERNECK, 1989).

A nova versão, registrada no LP Chico Buarque de Hollanda $n^{\circ} 4$, de 1970, conta com os seguintes versos:

Tem certos dias

Em que eu penso em minha gente

E sinto assim

Todo o meu peito se apertar

Porque parece

Que acontece de repente

Como um desejo de eu viver

Sem me notar

Igual a como

Quando eu passo no subúrbio

Eu muito bem

Vindo de trem de algum lugar

E aí me dá

Como uma inveja dessa gente

Que vai em frente

Sem nem ter com quem contar
São casas simples

Com cadeiras na calçada

E na fachada

Escrito em cima que é um lar

Pela varanda

Flores tristes e baldias

Como a alegria

Que não tem onde encostar

E aí me dá uma tristeza

No meu peito

Feito um despeito

De eu não ter como lutar

E eu que não creio

Peço a Deus por minha gente

É gente humilde

Que vontade de chorar 
A localização sócio-geográfica do subúrbio, neste caso, é mais precisa que na situação analisada anteriormente. O pano de fundo sobre o qual o eu lírico discorre é a periferia de uma metrópole, distante do meio rural, ainda que suas condições estruturais estejam muito aquém daquilo que se vê nos espaços modernos e desenvolvidos do centro urbano.

Outra característica evidente que distingue esta letra da anterior é o predomínio do discurso em primeira pessoa, que não procura exatamente narrar ou descrever um cenário. É a manifestação inequívoca de um momento de autorreflexão do sujeito lírico, que não se confunde na paisagem cantada, tampouco com seus tipos humanos. No entanto, ao se enternecer, o poeta fala em "minha gente", um sentimento de identificação que constitui o timbre do poema. Trata-se de uma ressonância do imaginário nacionalista de esquerda em vigor na década de 1960, período em que certos grupos de artistas e intelectuais se orientavam pelo ideal de "povo" e "nação" enquanto "totalidade" - ideal que não deixa de dissimular as relações de força intrínsecas à sociedade de classes.

Um dos pontos culminantes da sensibilização do sujeito lírico é talvez o instante em que ele expressa o desejo de viver sem se notar, denunciando como que uma crise de existência enquanto indivíduo numa sociedade bastante desigual. É possível ainda que essa postura esteja ligada ao desejo do individuo "moderno" de retornar a um modo de vida comunitário, em que a coletividade sobrepuja a individualidade. Todavia, deve-se sublinhar que essa sensibilização floresce quando ele "passa" no subúrbio, estando ele "muito bem, vindo de trem de algum lugar", para daí então sentir "como uma inveja 'dessa' gente", haja vista a sua "inocência" “aquela gente sem ver (...)" - e persistência diante de tantas adversidades. E é nesse ponto que se restabelece o distanciamento real entre o sujeito lírico e o contexto versado. O sentimento de inveja é suscitado quando ele reflete sobre a "inocência", "força" e "resistência" supostamente intrínsecas àquela "gente", e não quando pensa em suas condições materiais e sociais de existência.

Ao contrário do que observamos no caso anterior, em que predominava o caráter descritivo de um cenário mais preciso, numa espécie de prosa em verso em terceira pessoa e que, por isso, era menos passível à manifestação da subjetividade do 
autor desconhecido, constata-se na segunda versão uma transfiguração estética específica do meio social e cultural representado pelo sujeito lírico: não se comenta sobre esta ou aquela pessoa, este ou aquele casal, mas sobre aquela "gente" que não tem "com quem contar"; o olhar não se fixa num "casebre" específico, mas, como se estivesse diante de um livro antigo recém-encontrado, folheia um sem-número de páginas que trazem estampadas as "casas simples" que compõem um "mundo empoeirado". Assim, a narrativa de Vinicius e Chico Buarque se aproxima mais do registro da iconicidade, sintetizando imagens e emoções, enquanto que a letra do autor anônimo se aproxima de uma tendência narrativa em sentido estrito, ou seja, em que prevalece a descrição de um cenário (real ou não), ainda que em linguagem poética. ${ }^{13}$

Além disso, ouvindo o registro de 1951, logo concluímos que a paisagem construída e descrita sugere que esta era bem conhecida pelo sujeito lírico - referimonos aqui menos ao autor "real" que ao "poeta-narrador" implícito na obra, passível de ser "identificado" a partir da sua manifestação artística, e que pode assumir personalidades diferentes de acordo com a sua elaboração estética. Não que ele estivesse integrado àquele meio, conforme apontamos, mas, talvez por passar com frequência pela "estrada" de onde se podia ouvir "a voz da Rita numa canção dolente". Em outras palavras, a imagem que concebe é a de um instantâneo, o recorte de um microcosmo em que é possível nomear as personagens, descrever o cenário, enfim, um mundo em que o tempo não corre, divaga. Já na interpretação de 1970, ao contrário, a visão panorâmica e efêmera do poeta sentado na poltrona do trem em movimento não lhe permite fitar o pormenor, ainda que aqueles trilhos sejam percorridos constantemente. O único instante em que o tempo se dilata é quando o poeta se debruça na criação artística, introspecção necessária para que suas ideias, sentimentos e im-

\footnotetext{
${ }^{13}$ Ao falar em tendências "narrativa" e "iconicista", estamos nos baseando num referencial proposto por Luiz Tatit em algumas análises de canções. Partindo de reflexões oriundas da filosofia e história da arte, o autor afirma que também na música popular é possível identificar oscilações e inter-relações constantes entre essas tendências. Segundo Tatit, "a tendência narrativa se opõe e se complementa com a tendência iconicista, representada com radicalidade pelo concretismo em artes plásticas e literatura. Tudo ocorre como se a construção de um ícone (plástico ou linguístico), a partir da matéria de expressão do código, pudesse abstrair a narratividade já fartamente disseminada em quase todos os fenômenos sociais ou, com mais precisão, pudesse sintetizá-la na forma compacta de um objeto multifacetado. De outro lado, é como se a forma analítica da narrativa destrinçasse as dimensões ocultas de nossos conteúdos sociais e afetivos, animando e dinamizando suas relações em escala antropomórfica" (TATIT, 1995, p. 236-7).
} 
pulsos sejam traduzidos e materializados. Mesmo nos versos "São casas simples com cadeiras na calçada, e na fachada escrito em cima que é um lar", somos levados a imaginar um conjunto de casas, às quais se somam o toque singelo e enobrecedor da palavra "lar". Singeleza igualmente impressa em "Pela varanda flores tristes e baldias, como a alegria que não tem onde encostar", versos que, diga-se de passagem, acentuam a componente icônica da letra.

Assim, notamos também que o ponto de vista predominante na segunda versão é o do indivíduo não integrado ao espaço sócio-geográfico retratado, o que é absolutamente coerente com a posição social de Vinicius e Chico. Daí ser menos difícil identificar o sentimento impresso na canção: a melancolia, que subjaz todas as estrofes, matizando o enternecimento do poeta e conferindo a alguns versos um caráter "dolente".

Uma série de elementos e procedimentos musicais nos conduz a esses resultados: primeiro, quando as frases melódicas, sobretudo nas resoluções do consequente, apoiam-se em dissonâncias, como nas sétimas maiores do acorde de tônica (G7M), as quais sublinham as últimas sílabas dos versos "E sinto assim// todo o meu peito se apertar" (ver Fig. 6) e "Como um desejo de eu viver// sem me notar" (ver Fig. 7), por exemplo, reforçando a "tristeza" do sujeito lírico; segundo, quando se observa a recorrência de extensões nos acordes do tipo M7 (maior com sétima menor), como na dominante da tonalidade (D7), que vem acompanhada do intervalo de nona menor (b9) - uma dissonância - isso sem contar a nota da melodia que, na maioria desses casos, encontra-se na décima terceira maior (13) - uma consonância imperfeita.

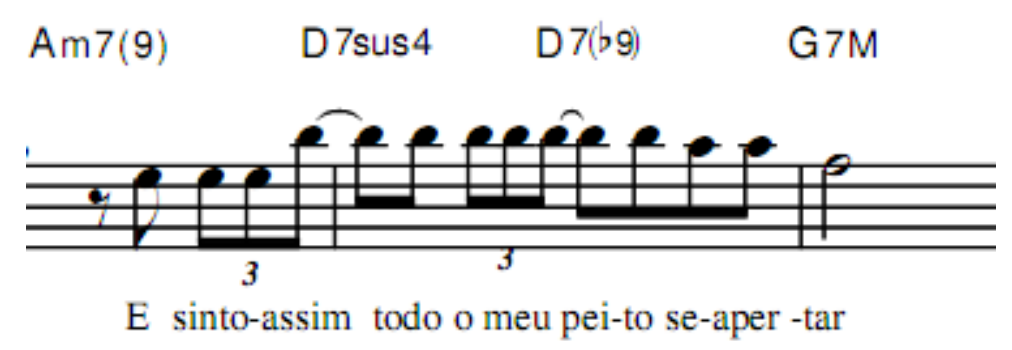

Fig. 6: Fragmento da primeira estrofe (seção A) de "Gente Humilde" (segunda versão - 1970). 


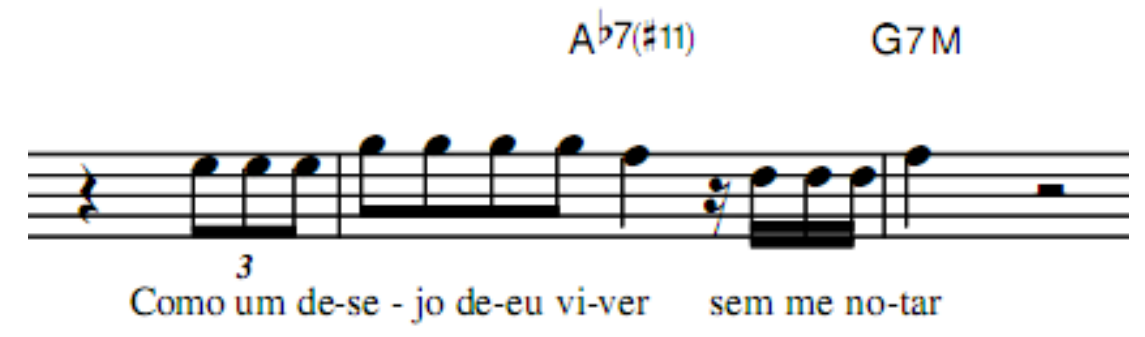

Fig. 7: Versos finais da primeira estrofe (seção A) de "Gente Humilde" (segunda versão - 1970).

Ao longo da música, ouvem-se ainda acordes dominantes apoiados pela décima primeira aumentada (\#11): de um lado, Ab7(\#11), substituto da dominante, secundando os fragmentos "viver sem me notar" e "alegria que não tem onde encostar"; de outro, F7(9)(\#11), substituto da subdominante menor, presente tanto em "como uma inveja dessa gente", quanto em "Peço a Deus por minha gente" (cf. partitura completa no anexo). Essas tensões resultam da imbricação entre harmonia e melodia, apresentando-se ora mais, ora menos dissonantes, enfraquecendo de qualquer forma o teor meramente "singelo" que possa eventualmente ser suscitado numa leitura pura e simples desses versos.

Apontando para uma crise de identidade do indivíduo que se depara cotidianamente com os inúmeros conflitos e contradições de uma sociedade desigual, o sentimento melancólico identificado nesta segunda versão de "Gente humilde" encerra ambiguidades que não se restringem ao contraste entre a posição social do sujeito lírico e o meio social que o inspirou. Referimo-nos, em especial, a um sentido passível de ser depreendido do único trecho da obra que foi alterado estruturalmente em relação à composição de Garoto e à primeira versão com letra. Trata-se do instante localizado entre os versos "Eu muito bem/ / vindo de trem de algum lugar" e "E aí me dá// como uma inveja dessa gente" (ver Fig. 8), ambos situados na segunda estrofe. Se considerássemos sua forma original, a progressão harmônica que corresponderia a essa passagem seria formada pelos acordes de Bm7(b5)-E7(b9)-Am7, ou seja, uma progressão do tipo II-V-Im que caminha por quintas descendentes e adquire uma sonoridade relativamente dissonante em função da estrutura dos dois primeiros acordes. Além disso, cabe ressaltar, sua resolução numa tríade menor (Am) conferiria à passagem, ainda que de maneira breve, certo teor de "tristeza" . 
Por outro lado, na interpretação de 1970, a transição entre os versos citados é pautada pelos acordes de Dm7-Em7-F7M-G7(b9)-C7M, progressão que, ao contrário da anterior, possui um movimento ascendente que caminha diatonicamente, concluindo num acorde maior (C7M). Esses fatores atenuam o caráter "dolente" da obra, ainda mais quando se ouve, no arranjo, a entrada mais substancial da família das cordas acompanhada de maior intensidade na execução instrumental, elevando a dinâmica da performance como um todo, pois, até então, o cantor era acompanhado apenas por violão e contrabaixo em pizzicato, em dinâmica mezzo piano, aos quais se somavam intervenções sutis dos contrabaixos (com arco) e violoncelos.

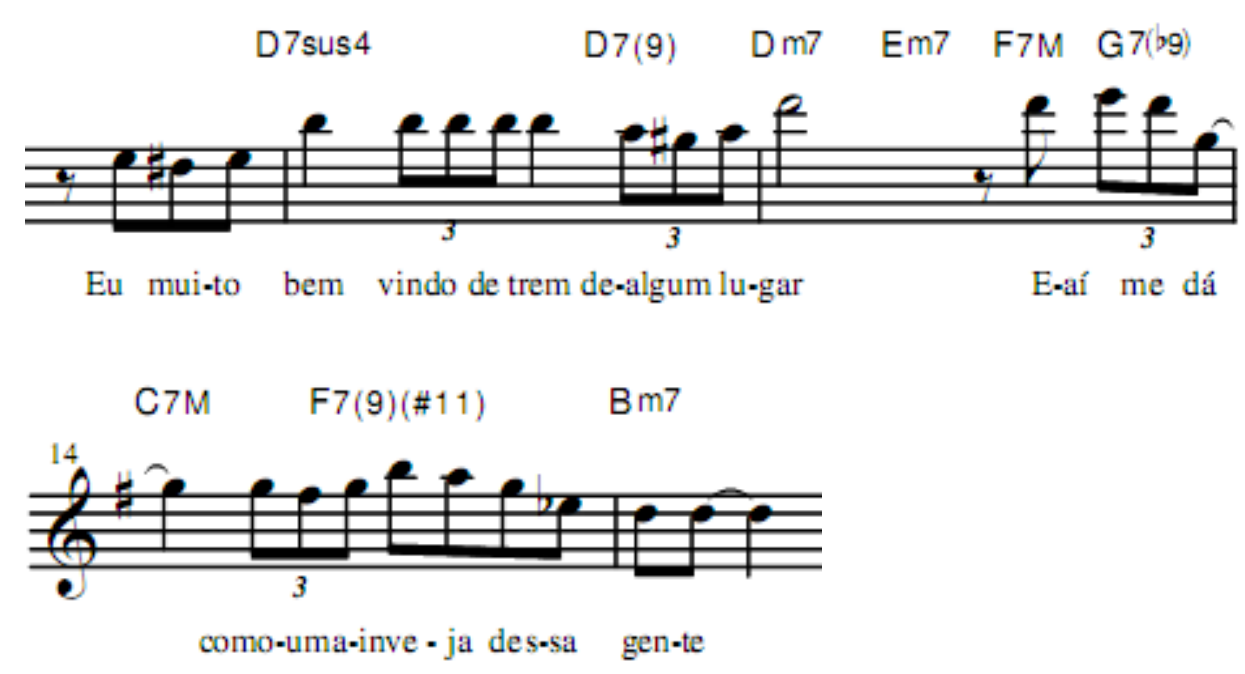

Fig. 8: Fragmento da segunda estrofe (seção A') de "Gente Humilde" (segunda versão - 1970).

Esse breve momento de expansividade da composição e do arranjo vai ao encontro do sentimento de conforto daquele que, "muito bem", vinha "de trem de algum lugar", enfraquecendo por um instante o tom melancólico predominante na canção - embora este ressurja logo em seguida com o F7(9)(\#11), um acorde dissonante que acompanha o verso "como uma inveja dessa gente", em que a melodia sublinha as notas que compõem a estrutura harmônica num movimento descendente (ver Fig. 8).

Todavia, ocorre o inverso no fragmento que corresponde a essa passagem localizado na última estrofe. Neste caso, a estrutura musical comentada anteriormente - Dm7-Em7-F7M-G7(b9)-C7M - marca a transição entre os versos “Feito um des- 
peito// de eu não ter como lutar" e "E eu que não creio// Peço a Deus por minha gente" (ver Fig. 9). É nítida, aqui, a manifestação de certa angústia do sujeito lírico ao ver tolhida a possibilidade de agir ou reagir em prol dos desfavorecidos. Mas a sua crise é ambígua, haja vista sua disposição em recorrer à "ajuda divina", pois, enquanto intelectual, imagina-se que esse tipo de atitude não lhe conviria. Aliás, tem-se aqui a expressão da autoimagem de um intelectual que ainda se vê enquanto "sujeito da história", representação em voga entre grupos de esquerda na década de 1960. No entanto, coincidindo com o momento em que a performance apresenta um crescendo, seguido de uma resolução num acorde maior, o sentimento "aflitivo" explícito nesses versos é atenuado, afastando-se do mero sentimentalismo. Ou seja, entre a angústia e a expansão afetiva, chegamos mais uma vez à melancolia.

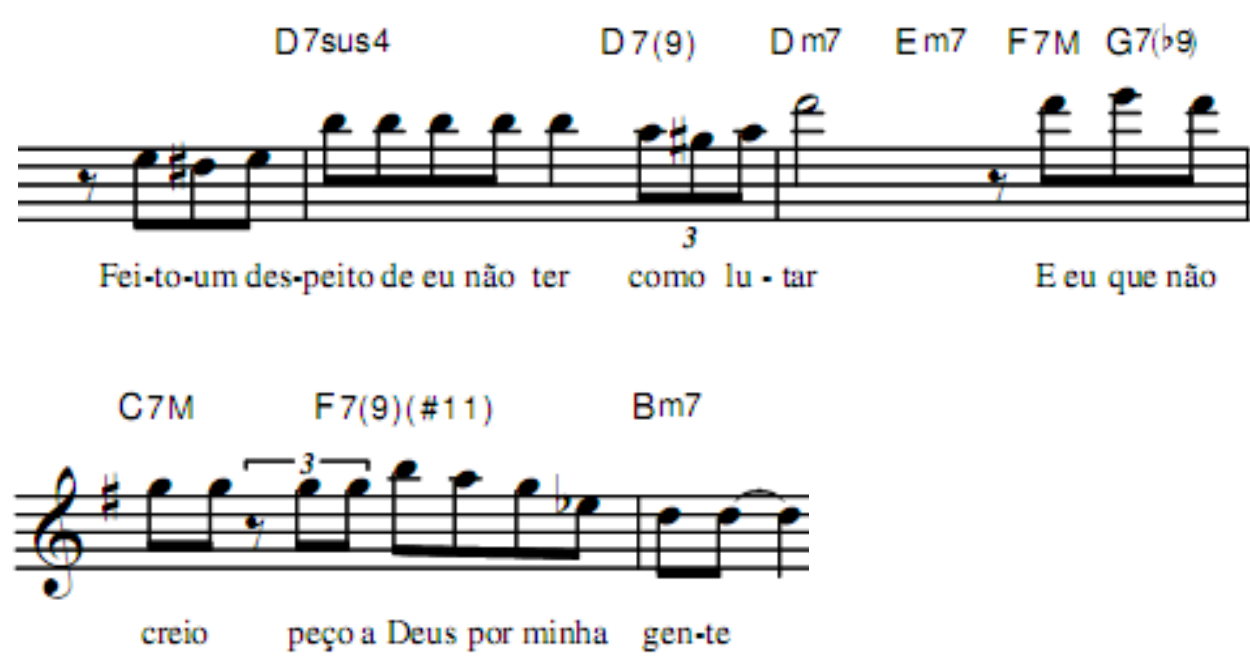

Fig. 9: Fragmento da última estrofe (seção A') de "Gente Humilde" (segunda versão - 1970).

O mesmo procedimento analítico nos conduz a resultados análogos quando avaliamos os instantes finais de cada exposição do tema (segunda e quarta estrofes). Na conclusão da primeira parte, por exemplo, ouvem-se os versos "Que vai em frente// sem nem ter com quem contar" sendo sublinhados pelos acordes de A7(13)D7(b9)-G7M, uma progressão do tipo II7-V7-I (ver Fig. 10). Na primeira versão, o trecho correspondente havia apresentado o acorde de Am7(b5) no lugar de A7(13). Além disso, a melodia se encontrava apoiada exatamente na quinta diminuta (b5) daquele acorde (Am7(b5)). Ocorre, porém, que na mudança harmônica entre as ver- 
sões a nota de apoio também foi alterada, deslocando-se no segundo caso para a quinta justa do acorde de A7(13). Este, curiosamente, mostra-se mais coerente com a resolução em G7M que o acorde de Am7(b5), pois, as progressões do tipo IIm7(b5)V7 concluem normalmente em tríades menores - se assim o fosse, encontraríamos um Gm em vez de G7M.

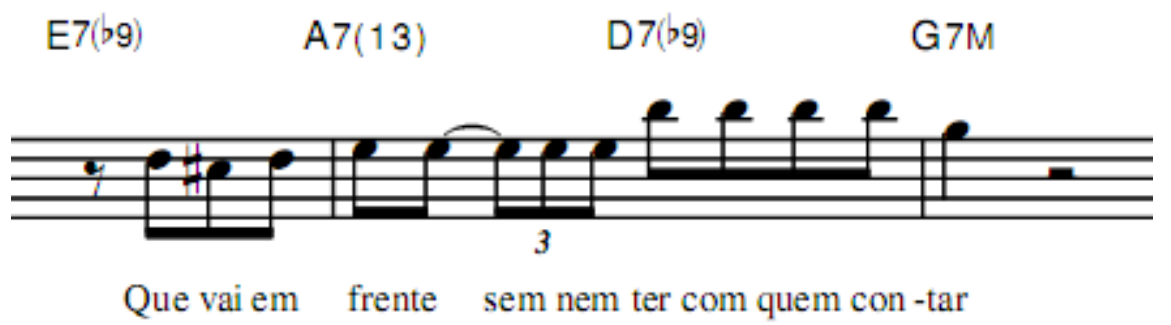

Fig. 10: Verso final da segunda estrofe (seção A') de "Gente Humilde" (segunda versão - 1970).

Não obstante, é no findar da progressão, quando a nota da melodia repousa na fundamental do acorde de tônica (G7M) e coincide com a última sílaba do verso "sem nem ter com quem contar", que o caráter "dolente" aí impresso se transforma, passando a coexistir com o toque "singelo" oferecido pela sonoridade da música.

Mas não há um instante em todas as estrofes da canção que expresse melhor a dor sentida pelo sujeito lírico que nos últimos versos. Em “É gente humilde// que vontade de chorar" (ver Fig. 11), ouve-se o poeta no momento grave da sua sensibilização, estando ele prestes a chorar. É como se ele estivesse no último suspiro, no silêncio trêmulo que precede as lágrimas, como se aquela "tristeza" estivesse consumando sua capacidade de "lutar".

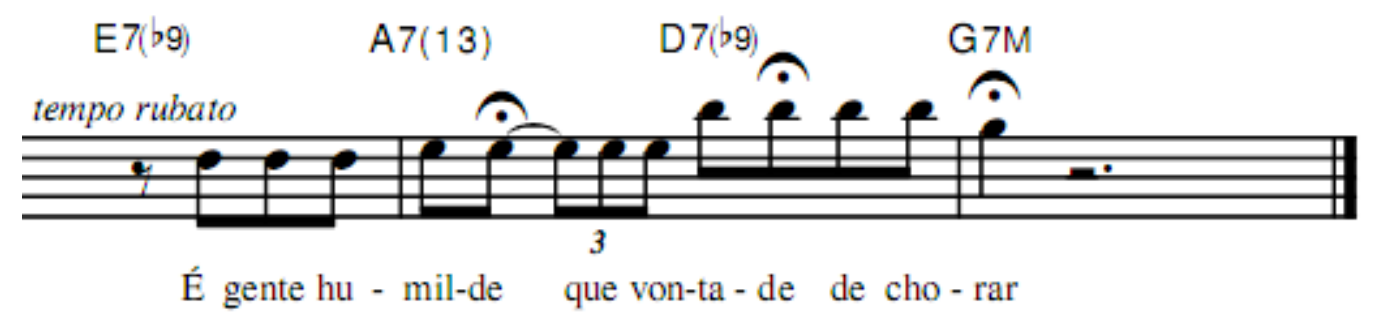

Fig. 11: Último verso de "Gente Humilde" (segunda versão - 1970). 
Na interpretação de Chico Buarque, vale ressaltar, o andamento regular da performance é suspenso a partir dessa passagem, sendo conduzido em tempo rubato até o fim da canção. Além disso, o violão silencia e cede espaço às breves intervenções das cordas. Esse procedimento contribui sobremaneira para que a expressividade aflorada seja acentuada, assim como o prolongamento das vogais empreendido pelo cantor, sobretudo quando alcança e sustenta a décima terceira do acorde de D7(13) - consonância imperfeita -, nota localizada na região aguda, e que precede a resolução na fundamental do acorde de G7M, situada uma terça maior abaixo. E por concluir na estrutura mais consonante de toda a música, a dor manifestada pelo sujeito lírico neste final é novamente amenizada, tornando-se "derramada para dentro", 14 sem ser meramente sentimental. Em suma, entre a dolência dos versos e a alegria contida da música, encontramos uma vez mais a melancolia.

Conforme apontamos em alguns momentos, o sentimento melancólico pode estar relacionado à crise de identidade do sujeito no mundo moderno, que se vê inserido numa sociedade profundamente desigual e que parece se transformar num ritmo cada vez mais intenso. No entanto, vale lembrar, essas transformações não se restringem ao plano infraestrutural. Não por acaso, Vinicius de Moraes e outros intelectuais e artistas do período se aproximaram do universo popular - o morro, o campo e o nordeste foram as tônicas dessa fase -, vestindo por vezes personas sensivelmente contrastantes se comparadas às suas origens sociais ou aos seus capitais culturais. Vinicius, por exemplo, identifica-se em "Samba da Benção" (1962) como “o capitão-do-mato (...), poeta e diplomata, 'o branco mais preto do Brasil', na linha direta de Xangô". É possível que essa remissão seja um mero recurso estético da canção. Mas, se voltarmos ao ano de 1953, época em que o poeta e diplomata ainda falava em "negro de alma branca" quando pensava estar elogiando algum sambista da "velha guarda" (MORAES, 2008, p. 65); época em que era capaz de recomendar à gravadora Continental que esta colocasse "no groove música cada vez melhor - com um pouquinho menos de baiões" (MORAES, 12-18 jul. 1953, p. 2), entretanto; se considerarmos a recorrência da temática afro-religiosa em algumas de suas obras tardias; e, por fim, se

\footnotetext{
${ }^{14}$ Essa expressão foi cunhada por Chico Buarque, e se refere às composições de Tom Jobim. Ver: SOUZA\& ANDREATO, 1979, p. 49-56 (publicado originalmente na revista Veja de 12 mai. 1971, apud GARCIA, 1999, p. 127-8)
} 
lembrarmos que foi graças a tais aproximações e inspirações que o seu "medo total de avião" desapareceu, a despeito do caráter anedótico desse fato, somos obrigados a reavaliar transformações estético-ideológicas como essas e tomá-las enquanto metamorfoses reais, ou seja, enquanto auto-imagens redefinidas de acordo com o processo sócio-histórico, e que podem estar apontando para um fenômeno mais amplo e complexo.

Nesse sentido, se pensarmos na conjuntura política do Brasil entre os anos 1960 e 1970, quando a expectativa da "revolução social" de alguns grupos parece ter desaparecido sob o impacto do AI-5; bem como na condição sui generis de artistasintelectuais assumida por Vinicius e Chico - mas também por Nara Leão, Caetano Veloso, Gilberto Gil e muitos outros -, nesse contexto de grande turbulência e repressão aos opositores do regime militar, as crises intersubjetivas que afligiram os agentes sociais ligados ao ideario de esquerda são mais bem compreendidas, embora não plenamente explicadas. Vale mencionar ainda que, a essa conturbação política, somava-se o agravamento da exclusão social dos contingentes populacionais de baixa renda concentrados nas periferias dos centros urbanos, um processo sócio-histórico diretamente relacionado ao intenso êxodo rural em curso entre os anos 1950 e 1960 no Brasil (FERNANDES, 2008). Outro ponto de vista em vigor nessa fase de transição era o tratamento idílico e folclorizante mantido por alguns grupos intelectualizados ante o elemento popular (negro ou rural), a exemplo do que apontamos na primeira versão de "Gente humilde", chegando a interpretá-los por vezes em chave humorística, pejorativa ou caricatural.

Todavia, os momentos de crise apontam também para a "possibilidade de novas significações" das manifestações artísticas (GAGNEBIN, 1994, p. 18). É isso o que observamos, por exemplo, na produção de Chico Buarque entre as décadas de 1960 e 1970. Nessa fase, o compositor se alinha a uma tendência da esquerda brasileira que privilegiava a temática popular, por vezes voltada ao trabalhador, ao proletário - a classe potencialmente revolucionária, segundo a orientação marxista ortodoxa. Daí encontrarmos obras de relevo como "Funeral de um lavrador", "Pedro Pedreiro", "Até segunda-feira" e, principalmente, o disco Construção (1971). Além da composição homônima, este $L p$ traz canções como "Cotidiano", "Deus lhe pague" e 
"Minha história (Gesúbambino)", por exemplo, todas alinhavadas pela temática da classe trabalhadora e o seu dia-a-dia, estabelecendo um confronto "velado" com o regime ditatorial. Aliás, embora afirme que a sua participação na letra de "Gente humilde" tenha sido irrisória, o breve retrato do subúrbio da grande cidade nela inscrito vai ao encontro da temática recorrente em sua produção nesse período.

A partir desses dados, pode-se dizer que, na segunda versão de "Gente humilde", a manifestação do sujeito lírico não engendra apenas uma crise intersubjetiva do artista-intelectual, e tampouco se restringe à sua identificação e sensibilização ante o elemento popular. Mais do que individual, ouve-se a expressão de uma representação social que circulava no imaginário de setores da esquerda na década de 1960. Acontece, porém, que esse imaginário é tensionado pelos desdobramentos políticos do pós-1968, encontrando-se em vias de redefinição, na medida em que valores e projetos estético-ideológicos que orientaram e marcaram uma parte da produção artística nacional daqueles anos se mostram contraditórios ante a nova realidade. Daí propormos, a partir do referencial de Norbert Elias, a possibilidade de a versão composta por Vinicius e Chico constituir a manifestação de um “eu-nós” (ELIAS, 1994, p. 146-51) em crise, ou seja, considerando o fato de que toda expressão individual é sempre social, uma vez que todo indivíduo carrega consigo o habitus de um grupo uma "composição social" interiorizada pelos indivíduos que responde pelos "automatismos" e "condicionamentos" que precedem nossas ações e a nossa consciência (ELIAS, 2006, p. 127-52) é lícito supor que essa obra traduz, até certo ponto, a crise do artista-intelectual que se vê enquanto "sujeito da história", uma autoimagem em vias de decomposição entre 1960 e 1970. Em última instância, a própria ideia de "nação" enquanto "totalidade", implícita nessa autoimagem igualmente arraigada num habitus social mais amplo, parece se enfraquecer com os desdobramentos políticos e sociais que pautaram a fase mais repressiva da ditadura militar no Brasil.

\section{Considerações finais}

Cotejando os resultados das análises anteriores, torna-se evidente o caráter contraditório e ambivalente das criações artísticas de agentes sociais intelectualizados ou de classe média ligados à canção popular de massa. Igualmente significativo é o 
fato de que tais contradições e ambivalências são evidenciadas pelo confronto entre letra e música. Em outras palavras, é como se a composição de Garoto, em sua versão instrumental, fosse capaz de revelar o momento de falsidade da parcela ideológica sedimentada nas letras compostas futuramente.

Como vimos, na primeira versão de "Gente humilde" a condição de pobreza é naturalizada. Nela, a transfiguração estética da realidade parece limitada em função do caráter narrativo e descritivo da letra. Todavia, esta é acentuada na medida em que tenta dissimular uma concepção tipicamente "burguesa" acerca do populário nacional, ao qual são imputadas "inocência", "pureza" e "felicidade" mesmo conhecendo-se a precariedade das suas condições materiais e sociais de existência.

Já a segunda versão dissimula esse imaginário da "classe média esclarecida" brasileira de modo distinto. A remissão do sujeito lírico ao populário e a sensibilização ante suas condições de vida tingem a superfície da obra. Este enternecimento se mistura à identificação do poeta com a "gente humilde", os quais supostamente se confundem, formando uma "totalidade", sobretudo quando se ouve expressões como "minha gente". Uma das contradições dessa postura reside no conflito entre a autoimagem do autor enquanto "sujeito da história", então corrente no meio artístico e intelectual de esquerda dos anos 1960, e a sua tentativa de transformação do "povo" em "sujeito da história" (KRAUSCHE, 1984, p. 6), movimento mais bem representado pela atuação e produção artísticas dos CPC's da UNE no mesmo período. Segundo Marilena Chauí, esses grupos também imputavam às massas "passividade, imaturidade, desorganização e, consequentemente, um misto de inocência e violência” que justificavam “a necessidade de educá-las e controlá-las para que” subissem “corretamente ao palco da história” (CHAUÍ, 1980, p. 61 apud KRAUSCHE, 1984, p. 10). Nesse sentido, Sebastião Uchoa Leite destaca que, se a "politização" era uma maneira de conscientizar o "povo" em direção à sua autonomia política, "apossar-se de suas formas artísticas para lhe oferecer um novo conteúdo político" era "implicitamente uma negação da sua capacidade de arbítrio" (LEITE, 1965, p. 279 apud KRAUSCHE, 1984, p. 9). Daí o caráter contraditório e, porque não, autoritário desse “iluminismo vanguardista" da década de 1960 (CHAUÍ, 1980, p. 60 apud KRAUSCHE, 1984, p. 10). 
Assim, pode-se dizer que a segunda versão também atua no sentido de naturalizar uma hierarquia social profundamente desigual, condição esta historicamente determinada, mas que se revela na obra apenas enquanto elemento interno (forma) - de modo não aparente e não imediato - que foge às intenções do autor, o qual se mostra, no plano externo (conteúdo), sensibilizado e relativamente politizado ao "pensar" na "gente humilde".

\section{Referências}

ADORNO, Theodor W. Introdução à Sociologia da Música: doze preleções teóricas. São Paulo: Editora Unesp, 2011.

A indústria cultural. COHN, Gabriel (Org.). Theodor W. Adorno: Sociologia. São Paulo: Ática, 1986.

ANTONIO, Irati. \& PEREIRA, Regina. Garoto, sinal dos tempos. Rio de Janeiro: FUNARTE, 1982.

BELLINATI, Paulo. The Guitar Works of Garoto, vols. 1 and 2. San Francisco-CA: GSP, 1991.

BOURDIEU, Pierre. A Distinção: crítica social do julgamento de gosto. São Paulo: Edusp; Porto Alegre, RS: Zouk, 2008.

CANDIDO, Antonio. A personagem do romance. In: (org.). A personagem de ficção. 9. ed. São Paulo: Perspectiva, 1992.

Literatura e Sociedade: Estudos de Teoria e História Literária. 11. ed. Rio de Janeiro: Ouro sobre Azul, 2010.

CHAUÍ, Marilena. Cultura e Democracia: o discurso competente e outras falas. São Paulo: Editora Moderna, 1980.

ELIAS, Norbert. A Sociedade dos Indivíduos. Rio de Janeiro: Zahar, 1994.

. Escritos E Ensaios, 1: Estado, processo, opinião pública. Rio de Janeiro: Jorge

Zahar Ed., 2006.

FERNANDES, Florestan. Mudanças sociais no Brasil. 4. ed. São Paulo: Global, 2008.

GAGNEBIN, Jeanne Marie. Walter Benjamin ou a história aberta. (Prefácio) In: BENJAMIN, Walter. Magia e Técnica, Arte e Política: ensaios sobre literatura e história 
da cultura; tradução de Sergio Paulo Rouanet. 7. ed. São Paulo: Brasiliense, 1994, p.719.

GARCIA, Walter. Bim Bom: a contradição sem conflitos de João Gilberto. São Paulo: Paz e Terra, 1999.

KRAUSCHE, Valter. A Rosa e o Povo: arte engajada nos anos 60 no Brasil. São Paulo: Dissertação de Mestrado, PUC-SP, 1984.

LEITE, Sebastião Uchoa. Cultura popular: esboço de uma resenha crítica. Revista Civilização Brasileira, Rio de Janeiro, n. 4, setembro de 1965.

MELLO, Jorge. Gente Humilde: Vida e Música de Garoto. São Paulo: Edições SESC SP, 2012.

. Gente humilde (versão original). Sovaco de cobra, 20 set. 2007. Disponível em: <http:/ / sovacodecobra.uol.com.br/2007/09/gente-humilde-versao-original/>.

Acesso: 12 set. 2013.

MORAES, Vinicius de. Samba falado: crônicas musicais. Rio de Janeiro: Beco do Azougue, 2008.

. Diz-que-Discos. Flan, Caderno "Mulher, mundanismo, arte e passatempo", n. 14, 12-18 jul. 1953, p. 2.

SAROLDI, Luiz Carlos \& MOREIRA, Sônia Virginia. Rádio Nacional: O Brasil em Sintonia. Rio de Janeiro: Jorge Zahar Ed., 1984.

SOUZA, Tárik de. \& ANDREATO, Elifas. Entrevista: João Gilberto. Em:

Rostos e Gostos da música popular brasileira. Porto Alegre, RS: L\&PM, 1979, pp. 49-56.

TATIT, Luiz. O cancionista: composição de canções no Brasil. São Paulo: EDUSP, 1995.

WERNECK, Humberto. Chico Buarque: Letra e Música. Rio de Janeiro: Companhia das Letras, 1989. 


\section{Gente Humilde ( $1^{\mathrm{a}}$ versão)}
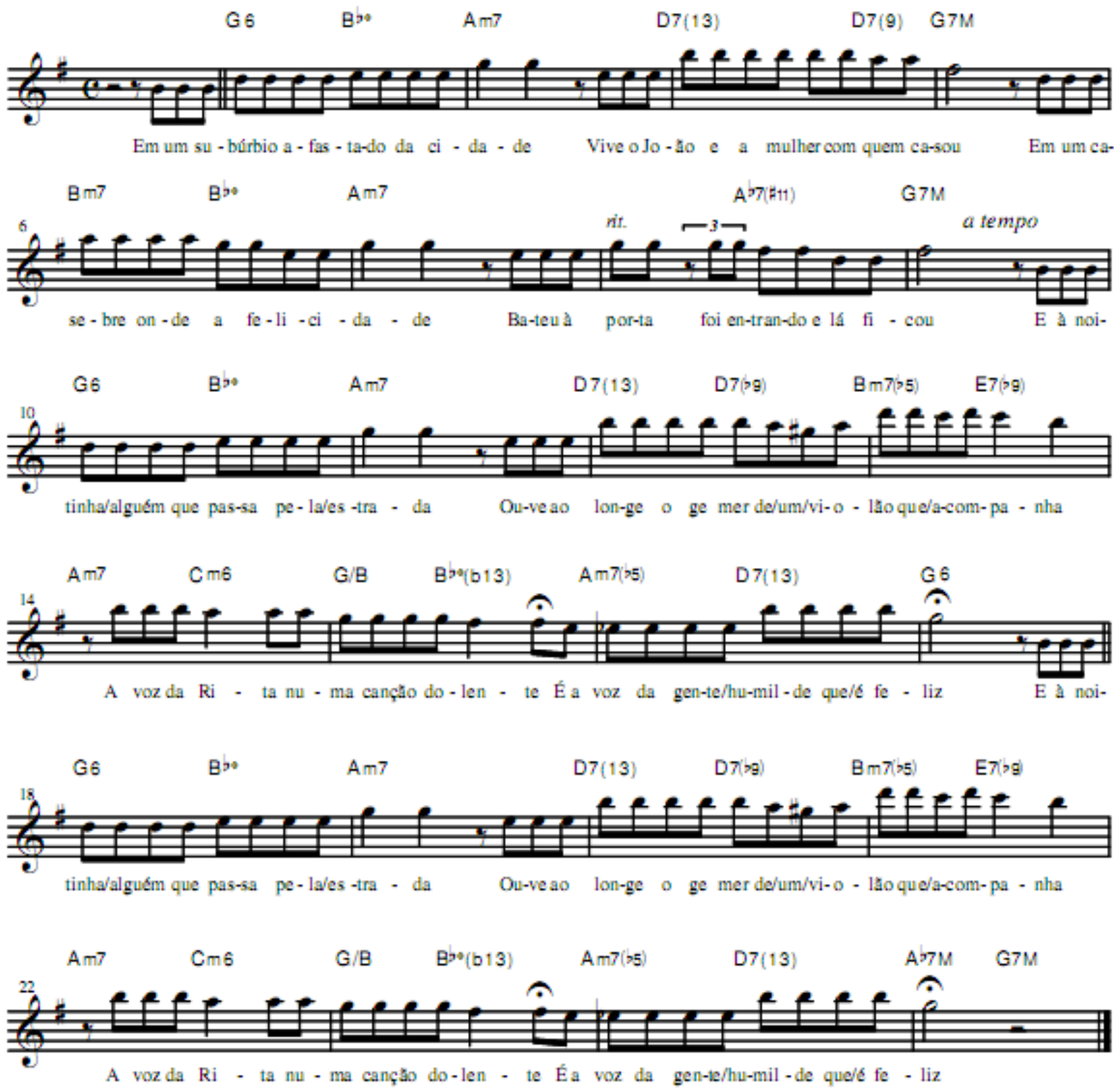


\section{Gente Humilde}

Garoto, Chico Buarque, Vinicius deMoares
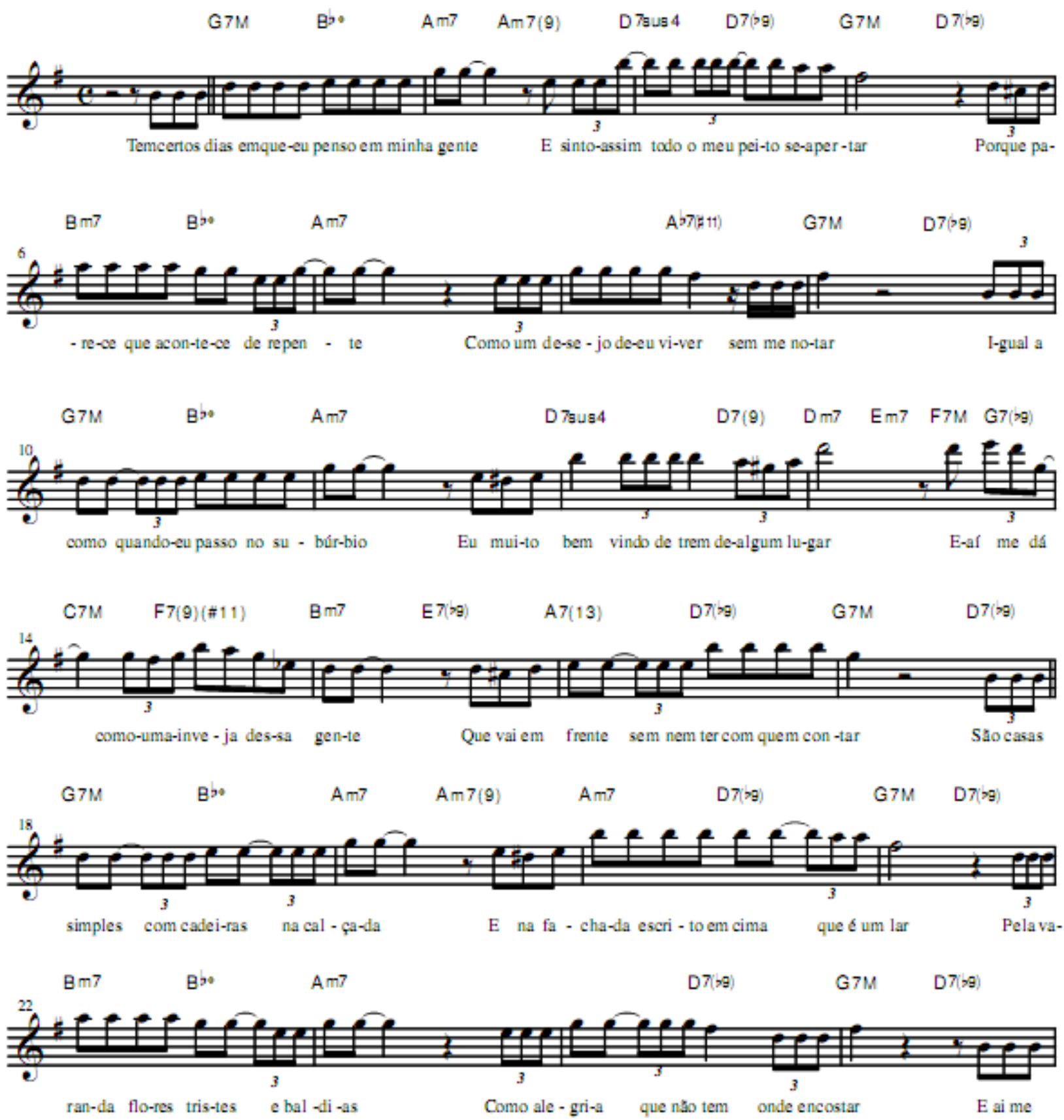

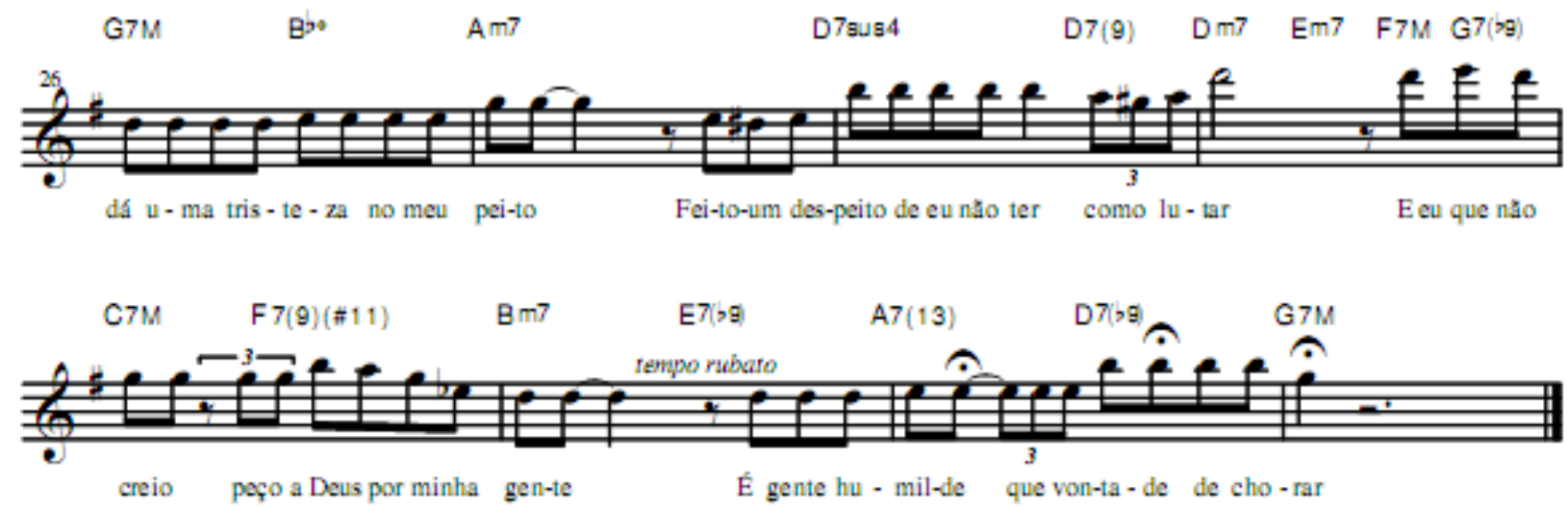